\title{
White Male Privilege: An intersectional deconstruction
}

\author{
Matthew J. Etchells, ${ }^{1}$ Elizabeth Deuermeyer, Vanessa Liles, Samantha Meister, Mario Itzel Suarez, \\ and Warren L. Chalklen \\ Texas A\&M University, College Station, TX
}

\begin{abstract}
This research saliently deconstructs the philosophical writing of a white, privileged male by five diverse academic peers by using a methodology of deconstruction to analyze the initial author's writing. Their reflects on his nascent perspectives address the stages of racism, mea culpa, the relationship between privilege, oppression, and classism, a feminist perspective, binary, and intersectionality. Further analysis connote for the need to deconstruct privilege in a literary context and to develop an autoethnography to fully delve into privilege beyond a superficial and neglectful narrative.
\end{abstract}

Keywords: Privilege, deconstruction, intersectionality, race, gender, and male privilege

\section{Introduction}

Male privilege exists due to the benefits reinforced by male-centric social norms which stem from patriarchal systems developed in the present and historically (Case, Iuzzini, \& Hopkins, 2012; Coston \& Kimmel, 2012). Recognition that that "we all have both privilege and disadvantage...can produce empathy and understanding that goes against polarization and bifuricated thinking about victims and victimizers" (McIntosh, 2012, p. 203). In addition, the nature of Whiteness is often invisible in discussion of White allies and multiculturalism (Damgaci \& Aydin, 2013; Helms, 2017; Michou, Mouratidis, Ersoy, \& Uğur, 2016). While male privilege may extend to any male, Whiteness is the "overt and subliminal socialization processes and practices, power structures, laws, privilege, and life experiences that favor the White racial group over all others" (Helms, 2017, p. 718), and refers specifically to the White, heterosexual male subgroup. Research on deconstructing privilege, especially male privilege, is limited and mostly reports on student qualitative responses to how activities centered around privilege contributed to their learning of the subject, and not on quantitative measures of their understanding of inequalities or privilege (Case, Hensley, \& Anderson, 2014; Citamak \& Yigit, 2012).

In fact, many students feel that the purpose of these types of activities are to diminish, alienate, or denigrate those who are White, which would be counterproductive and pointless and is likely not the case of the professor or instructor (Lund \& Carr, 2015; Yigit, 2017). This, among other feelings a professor might feel during the course of instruction on privilege such as multicultural perfectionism and the dreaded imposter syndrome, makes it a difficult subject to breach (Smith, Kashubeck-West, Payton, \& Adams, 2017). Yet, it is important for pre-service teachers as well as anyone preparing to enter any classroom environment, like the authors of this paper, to examine their own perceptions of privilege and multicultural practices. Research has shown, however, that the intercultural sensitivity of many pre-service teachers is not adequate (Kopish, 2016; Tarman, 2012 Yurtseven \& Altun, 2015) and that teachers often have low self-efficacy in terms of delivering a culturally responsive education (Damgaci \& Aydin, 2014; Karatas \& Oral, 2015), resulting in many students reporting communication difficulties and discrimination (Corona et al., 2017).

\section{Methodology}

This research began as a philosophical writing process to deconstruct a white male's sense of privilege and, at the time of writing, this white and privileged, male from England felt he had gleamed an educated level of awareness of his privilege.

After the initial writing, as a research exercise, five diverse colleagues were asked to read and write iteratively and using a recursive method to respond to his reflection based on their individual perspectives. From the researchers perspective he perceived he had asked a Latina, an African American female, a White female, a Latino transgender male, and a White South African male to write through their lenses.

The responses vary greatly and are unique to each individual beyond their personal description and thought and attention should be paid to their focus and style of their response, engagement with the text, or the degree of illumination of the initial writing. The writing and responses offer valuable insight into the perspectives and challenges diverse colleagues face when approaching discussions of privilege at

\footnotetext{
${ }^{1}$ Corresponded author; matthewetchells79@tamu.edu
} 


\section{Chalklen}

predominantly white institutions (PWIs) and offer worth to the need for perpetual and not intermittent or random discussions around privilege and creation of space and opportunity for diverse collegial engagement in complex conversations.

By inviting multiple diverse researcher to deconstruct Etchells' initial text this research provides an intriguing nexus between philosophical deconstruction and literary deconstruction, as the initial writing was a philosophical venture following the work of McIntosh (1990) and the subsequent reflections were, in essence, literary deconstruction. Through bridging deconstruction between a philosophical space and a literary space, the text is thus focused via an intertextual sphere (Holland, n.d.) and deconstructed by Slattery (2013, p. 298) definition of deconstruction as a

Sophisticated method of critical analysis of human artifacts such as written documents, textbooks, artwork, musical compositions, films, media, and the like. Deconstruction can include contextualizing, evoking, troubling, historicizing, challenging, analyzing, and interrupting.

\section{Preliminary Reflection Matthew J. Etchells}

Knowing thy self in a global context goes far beyond a modernist view of a final destination or structuralism and embraces a postmodernist and poststructuralist view which is "an assault on structuralism as well as an outgrowth of it" (Slattery, 2013, p. 304). In this research I deconstruct my privilege through Pinar's regressive, progressive, analytical, and synthetical moments. In this sense, I am able to understand the eschatological nature on my life as "dynamically interconnected rather than segmented on a linear time line (Slattery, 2013, p. 7). Therefore, some discussion on the stages of my life is necessary, but should not be maintained, as the prolepsis is in their intertwining and merging. I can see moments of my life recurring, others augmented with new insight upon their repetition, while others still reimagined with new possibilities.

I hope to open a conversation, which for me, has been slowly unpacking for my whole life to bring me to the thoughts in currently possess. For me the deconstruction from an American perspective emerged two years ago with a conversation on white privilege. However, to think that privilege and the race the privileged have maintained hegemony over is historically an American issue is to deny and recess the close links between people of color in America and Britain. I want to deconstruct my levels of privilege, starting with my white privilege. To not push oneself to speak, even naïvely, would lead to what Lacan (1960) refers to as castration. The total inability to express a desire and its juxtaposed idea of jouissance -ultimate expression. Many with white privilege choose the former leading them to feel awkwardness, avoid discussion, or refute the existence of their privilege.

The race issue in Britain is overshadowed and intertwined with a more overt class issue. Part of this may be due to a smaller Black population and larger Indian and Pakistani populations. Also, Britain never suffered the Jim Crow type laws and the level of segregation witnessed in America and South Africa. We did not have large plantations in Britain and most Africans served in houses. (Dixon, 2007). I think this deconstruction goes beyond the thirty-one-year difference abolition of slavery in Britain in 1834 (The Story of Africa -Slavery, 2015) and America in 1865 (The Story of Africa -Slavery, 2015) and to attempt to diminish my white privilege over people of color in Britain being less significant than I would have experienced growing up in America would only serve as a misrepresentation.

At school in England I was taught how the Vikings, Romans, Normans all invaded Britain, changing our cultural identity. I learnt French in school as a direct result of William the Conqueror's invasion of 1066. I was also taught the Kings and Queens of England, the rise of the British Empire, and the Industrial Revolution. I learnt all things come and go, the world is in constant flux, and, from my European perspective, that most countries have had an empire at some point...Britain, France, Germany, Spain, Portugal, Greece...the list is long... and European. In the deconstruction of my education, I now recognize "the school curriculum communicates what we choose to remember about our past, what we believe about our present, what we hope for the future" (Pinar, 2012, p. 30). Subtly nestled within our curriculum was "ideological hegemony" (Pinar, Reynolds, Slattery, \& Taubman, 1995). In individuals this produces a "distorted conception of their place in the sociocultural order and thereby serve to reconcile them to that place and to disguise the inequitable relations of power and privilege" (Pinar, Reynolds, Slattery, \& Taubman, 1995, p. 245).

I learnt nothing of the American Revolution, the Crusades, oppression, inequality, injustice, and massacre. At the start of Zulu (1964) starring Michael Caine, The Zulu's are attacking the British Army. Nobody knows why. They are portrayed as savages' intent on war. Not a single word is spoken by a Black actor during the entire film. The truth of this film now deeply saddens me. I learnt nothing of African British 
history, the Black Atlantic (Dixon, 2007) and never gave a thought as to where the Black population of Britain originally came from. In fact, the Black Atlantic slave trade meant "slavery thrust different African ethnic groups together in the slave forts of West Africa, on the slave ships of the "middle passage" and most significantly on the slave plantations and the huge houses of the rich in the Caribbean, America, and Britain. (Dixon, 2007). Thus, the African in America and the African in Britain were one and the same. Therefore, this is where the regressive moment is born, at the impetus of the creation of a system of privilege.

I had little reason to question where the two black students at a school of one thousand had come from. My best friend, Matthew, was adopted by white parents and Lucy had a twin who was white. I was too young to have the words or the questions to ask. Being English, in the mid 80's, we were taught not to ask awkward questions. He was my friend. He was different from me and he was treated the same as all the other students. This is long before multiculturalism in education. I grew up in an increasingly multicultural secondary school and overt issues of privilege were never discussed. This continued through College. It was when I took a course on feminism in my second year at Chester University that I was confronted with my male privilege. There were forty women and two other males. The two males had been in a relationship with each other since first year. We sat in a circle and all eyes were on the 'Man'. It was awkward and I wanted to run away. This class made me confront the privilege I have as a man, and the power and abuse of privilege. The fear and insecurity that was not part of my day. I was not interrupted when I spoke. I was not treated as weak and I did not need protecting. This was also when I became saliently aware I had height privilege. I would walk over to a group in discussion and automatically I would be noticed because I am tall. We have hidden sayings in our language and, when deconstructed, they are overtly predigested, 'somebody to look up to'.

In 2004, I moved to the United Arab Emirates, which had been ruled by the British until 1971 (UAE History, n.d.). Immediately the residual colonial hegemony was apparent. I was paid more than my Irish counterparts and quickly ascended to a leadership position gaining more responsibility each year. My white, male, height, and weight privilege were evident. This was the first time I realized speaking English and having a native English accent was also a form of privilege. Even though the school had Lebanese owners, many of the senior managers were British or had strong British roots. I was used as a recruitment tool and travelled all over Britain and Ireland. At this time, it was oblivious of the purpose I was actually serving and the "preserved social stratification" (Pinar, Reynolds, Slattery, \& Taubman, 1995, p. 249) I was maintaining. We maintained our privileged status by perpetuating the assumption white teachers are more educated than teachers from other countries. We would disguise this hegemony as only needing native speakers and only going to cities like Limerick, Glasgow, and Chester with mainly white populations. By doing this the education system served as a form of "selective tradition" to "privilege certain sets and orders of knowledge over others (Pinar, Reynolds, Slattery, \& Taubman, 1995, p. 251).

When I moved to Texas in 2013, I realized my accent was a form of privilege and this is when my experience was able to "spark understanding and engender a synthetical experience" (Slattery, 2013, p. 246). Until now my understanding of privilege had been linear, with each type of privilege becoming apparent when I was confronted with the opposite. I realized my male privilege in a feminism class. I realized my body privilege while doing Performing Arts. I realized my colonial privilege while teaching in the UAE. My "linear explanations [were] replaced by concepts of contemporaneousness, convergence, and synthesis." (Slattery, 2013, p. 244). In this moment, I can see my past, my present, and my future as a simultaneous experience. I can see who I was and why I perceived myself and those around me as I did, as I do, and as I will. I concur with the synthetical moment as "a reconstruction of the self and an experience of solidarity of the intellect, the body, the spirit, and the cosmos, as well as an intrinsic coherence of time, place, and meaning." (Slattery, 2013, p.244). I was who I was in that time and place, but also there was a part of me in the present and the future. I wanted to seek out otherness. Before I feel like crying and I felt like screaming.

The world of privilege I had inherited had been born from the murder, oppression, and pillage of my fellow human. It is a conversation that had been pushed so deep into the muddy waters of the British psyche that it had strained at its last breath and slowly drifted down to its death. I felt we had bifurcated ourselves as beings -them and us. We had achieved the dystopia Orwell, Wells, and Fitzgerald predicted. Now I embrace the other, I want to understand my privilege. The bifurcation that has been forced upon us male/female, white/colored, tall/short, heterosexual/homosexual all fade away in the synthetical moment. Seeing ourselves across time and space goes beyond the simplicity of a form, a vessel, a label. We are all part of each other. As globalization perpetuates, we move, experience, and understand, we will literally become part of each other too. For me the synthetical moment can go beyond an individual experience. 
For all the privilege I am aware of, there is a myriad I am not. This is not a conclusion, rather a beginning. I am an infant and my eyes are gradually opening wider to see and cannot be closed again.

\section{Peer Reflections \\ Elizabeth Deuermeyer}

Perhaps Etchells' view of the world came from Britain's history of colonization. Memmi (2013) stated in The Colonizer and the Colonized that "the colonial situation manufactures colonialists, just as it manufactures the colonized" (p.56). When we recognize colonization impacts both the colonizer as well as the colonized, we must also admit history is shaped by the people, but that people are also shaped by the situation, and the story told is often that of the colonizer. For any country with a strong history of colonization, such as both Britain and France, one can say that they have had great influence over millions of people, structuring their education, work, laws, and even shaping identities and how people contextualize themselves in the world. As decolonization occurred, and natives from colonized areas sought homes on the colonizer's home land, a clash often ensued. While France had full intentions to integrate natives from former colonies as French citizens, Britain never had such plans (Joppke, 1999), perhaps due to the images and myths that were portrayed of the colonized in justification for colonization in the first place.

Colonization in turn continues to shape Britain's national identity, something of which has changed and continues to change as a number of immigrants from far away British colonies arrive on shore to begin a new life. Through colonization, Britain gained first-hand experience at governing and controlling groups that were racially, ethnically, and culturally diverse, thus being able to decide the treatments and rights that were afforded to people considered "other". With the setup of Britain as a global hegemonic entity by the end of the eighteenth century, one could see how Britishness began to represent a state of empire, where the country flourished with the complacent and subservient dependency on others for survival (Gifford, Halsall, \& Gill, 2013). Consequently, when members of UK commonwealths remained in their respective areas, most British citizens were able to remain blind to the system of privilege that had been arranged years ago. This changed with commonwealth immigration, and social inequality became the principal experience for any person of color.

Etchells' inclination that the race issue in Britain is overshadowed by a class issue might be his way of easing guilt in our own hand in not only the global slave trade but also dehumanization and destruction of entire groups of indigenous populations. Although he might try to differentiate the experience of people of color in America from those in the UK, the comparisons between the two are quite similar. His country shook with similar movements that parallel the United States' period of Civil Rights in which the main debate on immigration during the 1950s and 1960s focused on how to control black immigration and to question the "desirability of letting into Britain a sizeable number of West Indian or Asian migrants" (Solomos, 1992, p.11). Black and other minority ethnic groups were subject to direct and indirect forms of racism masquerading as class issues, mainly unequal access to social and welfare services, leading to segregated communities where conflict between ethnic groups often ensued (Bagguley \& Hussain, 2008). As legislation was passed in the 1960s and 1970s in the United States, similar legislation was enacted in 1968 and 1978 with the Relations Act, aimed at what Gifford, Halsall, \& Gill (2013) call to be a solution to the persistent social disadvantages running rampant in those small ethnic communities. However, what also persisted was the insisting these were issues related to class, race or ethnicity.

The way persons view the world depends on their own understanding of such world. Consequently, the ways in which students were taught growing up in Britain's education system creates an ideology of comparisons between cultures, between the colonized and the colonizers, which leads to the cultural identities positioned in social, economic, and bureaucratic hierarchies. Etchells' identity is not something he ever had to question, because in the eyes of history, he is the colonizer, and he fits the mold of what his society has deemed as "normal". Thus, when he is confronted in situations where by identity and privilege is challenged and he must discuss issues of race, gender, class, etc., he does what most White people do in America, which is to shut down. Tatum (1992) identifies three major sources of resistance to learning about race and racism: 1) race is a taboo subject, especially amongst racially mixed groups; 2) many students are socialized to think of their country as just a meritocratic society, where everyone is melted together as one; and 3) many White students' first inclination is to deny prejudice because they recognize the impact it has on people, but cannot identify how it has impacted their own life.

While working with her White students in a psychology of racism course, Tatum (1992) watches and helps her students' progress through Helm's (1990, as cited in Tatum, 1992) six stages of White racial identity development where the racist self is abandoned and a non-racist White identity is adopted: Contact, 
Disintegration, Reintegration, Pseudo-Independent, Immersion/Emersion, and Autonomy. The Contact stage is characterized by a lack of awareness of cultural or institutional racism, and of one's own White privilege. A person in this stage might also have an irrational fear of people of color developed from stereotypes gained from family, peers, and even the media. When a person of color does not fit what a person in the Contact stage sees as "normal", he or she might make comments such as, "You're the whitest Black person I know".

A person might remain in the contact stage forever if their interactions are limited, but certain experiences, such as increased interaction with those who are different from him, can lead to the discovery of institutional racism, and leads the person into the second stage, disintegration. This is a particularly difficult stage, because feelings of guilt often accompany the discovery that racism in fact is not over. To ease this guilt that they may have played or do play a part in this racism, persons in disintegration attempt to ease these feelings, either by superficial acts or interactions with people of color. Many who start to become aware of racist jokes or comments made by friends or family will try to confront these, only to find their efforts are ignored or ridiculed. Worse yet, for some the feeling of guilt is so intense, they use denial of the existence of racism to ease their minds. This lays the foundation for the third stage of Reintegration in which a person finally accepts the reality of racism, but often blames or becomes angry with people of color as they identify them as the source for their discomfort.

With continued experience and interaction with those of different races or cultures, one finds himself in the Pseudo-Independent stage in which he abandons the idea of White superiority, but has not yet began to truly analyze his own part in racism and privilege, so he finds himself unintentionally maintaining the systemic and institutional racism he is trying to fight. In doing so, he feels uncomfortable with other Whites who are not yet at the same stage, and might try to realign himself with others who understand him. However, his unintentional continued participation in his own privilege often prevents him from fully aligning with people of color who might find his moves or motives skeptical.

In the Immersion/Emersion stage, faced with not really knowing what else to do, the person finds himself attempting to find a more comfortable way to understand himself and his history as a White person. Researching antiracist scholars or persons from the past are important to his understanding of his new identity. It is important for them to know that others have suffered similar identity crises, and this new positive image of the self pushes him into the Autonomy stage. In this stage, the person's anti-racist comments and actions are more consistent, and the person is able more easily identify and be accepted by persons of color because they are seen as more authentic. This stage requires an ongoing process of self-examination if he or she is going to be consistent in the behavior of their newly identified self.

\section{Vanessa Liles}

I have been asked to respond to the reflexive essay of one White man's discovery of his privilege, at the point of its infancy. In this response, I will critique the findings of Etchells' understanding of his privilege using the lens of Critical Race Theory as articulated by Bell (1992), Delgado (1989) and LadsonBillings and Tate (1995) thereby using a frame that defines racism as a systemic effort to oppress non-Whites through the use of White supremacy. In this section, I will address seven of Etchells' statements, which I offer for reconsideration to the author as well as suggest questions for further exploration; ultimately, suggesting an auto-ethnographic framework.

I hope to open a conversation, which for me, has been slowly unpacking for my whole life to bring me to the thoughts in currently possess

Etchells suggests, in the opening portion of the essay, that he has been working on the unpacking of his privilege his entire life, giving no treatment to the significant portion of his life when he had no awareness of the benefits afforded him in this privilege. In Decolonising the Mind (Thiongo, 1984), he takes great consideration, over the course of several essays, to document his work's rejection of his own culture, prior to his enlightenment. The reader of Thiongo understands his personal journey, including significant occurrences that were instructional to his paradigm shift. The trajectory in the essay deserves the same treatment. To spend several sentences laying the foundation to his positionality on race as well as his contributions to the oppression of others through his white privilege may well allow this writing to do more than seem a list of awakenings to his many assets, which are read as privilege points.

For me the deconstruction from an American perspective emerged two years ago with a conversation on white privilege... However, to think that privilege and the race the privileged have maintained hegemony over is historically an American issue is to deny and recess the close links between people of color in America and Britain 
From what emerges as a theme in the essay, Etchells takes a position that there is a sort of "oppression olympics" (Martinez, 1993) and depending on the perspective, England is either the gold medal winner or does not qualify for a position. I wonder at his idea of "an American" perspective" on white privilege? While, the oppression may look different in England than it does in America, the oppressed does not fare better under one system than another. The awareness of his privilege should walk hand-in-hand with an awareness of the oppression's effect on the marginalized group. Here, it stops at an awareness of the author's mea culpa within a series of awkward exchanges and "aha" moments.

Again, while acknowledging the infancy of this exploration of privilege, I will also be clear on missed opportunities to delve deeper into the full understanding of privilege. Here, in this quotation, Etchells presumes there is "a" race, which has been held captured by privilege? If he is using it as an all-encompassing term of non-White people, I assume and question the writer's implication that POC in America and, specifically, Britain have indistinguishable cultural and historical, oppression.

The race issue in Britain is overshadowed and intertwined with a more overt class issue. Part of this may be due to a smaller Black population and larger Indian and Pakistani populations.

In the author's statement which claims "the race issue in Britain" is complicated due to class and low numbers of Blacks, I wonder if this assessment comes from the writer's perspective or does he, who just opened the lines of discussion and his awareness of privilege, portend to declare race a minor player, second to the issue of class? From whose perspective does this declarative statement emerge? In critical race theory, racism is a system, which invades all aspects of our lives and is not subject to replacement because there are no individual acts, such as legislation, which can eradicate its pervasive oppression. Bell has likened it to alcoholism, in which an alcoholic will always be an alcoholic, no matter how long one goes without a drink ("Overview of Critical Race Theory", n.d.) In Britain, or America, racism is not suppressed it simply lives alongside its cousin, classism.

Further, for this reader, I critique the implication that numbers alone guide racism's oppressive weight. Using the lens of the author, one might imagine race is a matter of ratios of oppressed to oppressor. Again, this simple understanding comes without benefit of perspective. Had Etchells explored the available extensive literature, written from the perspective of the oppressed, such as the work of Walter Rodney (Rodney, Babu, \& Harding, 1981), the persistent theme of this essay, once I realized I have privilege, which has colored my view of the world, I will now see the world from my perspective but honor your oppression with the benefit of how it is experienced through my lens. - he would not have arrogantly stated the addition of his new perspective as "benefit". He may be guided to write a tome grounded in a methodological frame that would review the impact of oppression that is not qualified by ratios and comparisons of systems. His theoretical framework may be shaped by actual data and historical voices of the oppressed.

We did not have large plantations in Britain and most Africans served in houses

Again, the comparison is misguided if the writer does not understand the details and nuances of American slavery to begin with. The oppression of American slavery certainly manifested in enslaved persons working off the fields as well as in the fields (Keith \& Herring, 1991). Again, this comparison does more to undermine his aims to reveal his awareness of his privilege than it shows a true understanding of privilege. In fact, in true irony, his explanations are indicative of White privilege as they can create a historical narrative counter to actual facts.

The author may desire to base the reason he was awakened to privilege in America's gross racism, but it is also to say that he was not aware prior due to Britain's minimal racism. Perhaps, his lack of awareness was made clearer in his coursework in America, which addresses these issues in contrast to a European educational system that does not address such issues? Surely, it is not the mild manner and treatment of racism in Britain that allowed Etchells to remain unconscious to his behavior.

I think this deconstruction goes beyond the thirty-one-year difference abolition of slavery in Britain in 1834 ("The Story of Africa-Slavery", 2015) and America in 1865 ("The Story of Africa-Slavery", 2015) and to attempt to diminish my white privilege over people of color in Britain being less significant than I would have experienced growing up in America would only serve as a misrepresentation

Overall, McIntosh (1990) offers a guide for this type of deconstruction, which would complement Pinar's use of the regressive (Pinar, 2012). It is clearly not adequate when addressing the scope of this subject to use tools only available within your memories to deconstruct such a weighty matter. It is a brave first step, to be sure, but almost the precursor. I am reminded of the CEO of Starbucks and his attempt to address everyday racism by asking the baristas to engage in conversations on race (Carr, 2015). It was a horrible social media fail. I, unlike most of my contemporaries welcomed the attempt by a White business structure to tackle such a contentious topic but I was in the true minority. What the author is attempting is what racism 
needs, certainly, conversation between and across lines (Bucher, 2015). McIntosh sees the responsibility for Whites to spend from the wealth of their privilege bank accounts (McIntosh, 1990) and the author will see the reciprocal relationship of spending and gaining if he continues to use the tools of alternative narratives to history and discovery provided by the authors cited here.

The writer must also believe that, like his history, others have a history that does not start with oppression, inequality and injustice. To understand other nations and communities of people were thriving and developing, in time (if not ahead of time) with European nations and communities would allow the writing to be truly derivative of an informed meaningful reflection.

To this end, my final response to this initial reflexive essay is a suggestion to conduct an autoethnography, where the author becomes the subject and is placed within a cultural, political, and social space - one hefty with objectivity. The tracking of data will allow the writer an opportunity to apply objective analysis, conduct a literature review, discuss positionality, and more - all the elements of a solid qualitative research project, which is what this process calls for in order to avoid shallow rhetoric and narrow readings of history.

\section{Samantha Meister}

While I appreciate the time that Etchells has clearly devoted to both the examination and deconstruction of his own levels of privilege, I'm also quite happy to read that he temporarily concludes by acknowledging his infancy in this ongoing process. It is my intention to offer merely a small contribution to the discussion of privilege in an attempt to deepen the author's understanding of his position and to further advance the process of deconstruction.

As a white, heterosexual, female who has attained both a bachelor's and a master's degrees and is currently pursuing a doctorate, I too, acknowledge and understand the incredible amounts of privilege I possess. Speaking from another position of white privilege, the themes that resonated most for me from the original work largely surround the areas of gender and social class. It should be noted, that although the author and I share the same skin color, we represent strikingly different upbringings and positions within this socially constructed society within which we exist.

When initially approached regarding this project, Etchells seemingly selected a number of individuals who represented a variety of races, genders, and sexualities. I was asked to read the initial work, and offer feedback from my perspective. This act alone demonstrated that the original author had already somewhat identified a particular role each of the contributing authors was to play. My role, was that of the white female. While I truly believe that the original author was open to the possibility of our varied contributions, we had already all been assigned pre-selected perspectives to reflect upon: the white female, the Latina, the Black female, etc. The selection process and the unspoken assignment of roles to play, being requested and delivered by a white man, reinforces the societal pressures that each of the contributing authors is already required to succumb to on a daily basis by existing in the world of the white male.

Another structural concern throughout the entire original paper is that the author, a white male, analyzes his position of privilege by relying upon the words and academic works of other well-educated white men. While the works cited are undoubtedly seminal texts in the field of curriculum theory, the field of study that provided the language with which to begin the deconstruction of his own privilege; the author relies solely on these texts. At no point, does he seek out the words of women or persons of color. This is also present in the authors he chose to select for their representations of a dystopian society which he likens to his personal understanding of the society in which we are presently situated. Again, it seems as if the original author is interested in analyzing his position of privilege and beginning the work of deconstruction; yet he remains firmly devoted to the words and perceptions of whom he is trying to analyze rather than seeking the critiques of those outside the echelons of white male academia. While assumingly unintentional on the original author's part, this act of selecting valued perspectives simply reinforces the exclusion of marginalized voices from the conversation.

The original paper notes that the author first recognized the concept and prevalence of male privilege within his own experience in his second year at university, through participation in a course on feminism. The discussion that follows is fraught with dualisms and assumptions about the feminine experience. He recognizes his own position of privilege by reinforcing assumptions of women, stating: "the fear and insecurity that was not part of my day. I was not interrupted when I spoke. I was not treated as weak and I did not need protecting". First, these stated examples are the only elements of the feminine experience that the author chooses to focus on: weakness, fear, and legitimacy in terms of female thoughts and words. These statements pay no amount of respect to the strength, resilience, knowledge, or critical thought that women 


\section{Chalklen}

are capable of, and do little more than to demonstrate that the author has recognized the most superficial societally accepted assumptions of women.

Furthermore, the author's descriptions are highly problematic, specifically the statement "I did not need protecting". This statement implies that the author feels women are in need of protection, but he ends the conversation of his male privilege after this statement. He does not go on to discuss or deconstruct this statement. From whom does he feel women need protecting? Men? Society as a whole? Themselves? This statement further reinforces the assumption women are weak and cannot experience a full life independently. Additionally, although the author does not present the statement within the context of a dualism (i.e. weak versus strong), the absence of further explanation of his statements leads the reader to assume his statements are presented as such. Overall, the discussion of male privilege is incredibly superficial and neglects a nuanced discussion of his own actions and their impact on the women with whom he surrounds himself. Acknowledgement of male privilege is present; however, any sort of reflective analysis is strikingly absent.

The final element of the original paper that I feel deserves deeper discussion and reflection is the author's statement of "I wanted to seek out otherness..." This statement was made during the author's discussion of his realization of the synthetical moment in his understanding of privilege (Slattery, 2013). The statement in itself is problematic for a couple of reasons. The first is that by labeling whatever he is seeking as "otherness", he is still engaging in the bifurcation of his own conceptualization of the world. This still maintains a me-versus-them, self-versus-other manner of thinking. This bifurcation allows the self to maintain a position of superiority to the other, thereby reinforcing the stratification that is already present.

The second, and perhaps more problematic element, critique of the author's statement "I wanted to seek out otherness..." is that there is no discussion of the purpose of seeking out, as he states, otherness. My immediate assumption is that he is seeking out otherness in an attempt to satiate his own desires and needs for cultural knowledge and understanding. If this is the case, then the author is simply gratifying his own needs, which is no more than appropriation of the experience of the "other" for his own personal gain. Furthermore, if this seeking of otherness is for self-serving purposes, the author is likely exoticizing and fetishizing the other, rather than truly attempting to understand their experience. Brittany C. Slatton (2014) examines this mythologization of specifically black women by white men, examining both an historical perspective and current understandings through her sociological work. Slatton notes historically and currently, the "othering" of Black women has served to reinforce social and sexual stereotypes among white men that have allowed for the continued degradation and deligitimization of Black women as a group. Author one's initial statements within the original essay are dangerously reminiscent of many of the interview excerpts included in Slatton's work.

Overall, the original author is correct in his assessment that his understanding of his own privilege is in its infancy. He noted that "I had little reason to question" issues of race and gender within his childhood and adolescent experiences. It is only from his position of privilege that he is capable of making such statements. It is apparent this process of deconstruction is only in its beginning stages, and the process should be continued with fidelity moving forward. I am intrigued and encouraged to witness and assist in his process of deconstruction as his "eyes are gradually opening wider to see and cannot be closed again".

\section{Mario Suarez}

When Etchells asked me to read his paper and critique it from a gender and sexuality perspective, I did not know what to expect. I have lived gender and sexuality all my life, and suddenly within the last year or so upon starting the doctoral program, I was seen as an "expert" in gender and sexuality because I am an openly transgender man. It took me a little while to realize that, being the only Latinx person in my cohort and the one of the first openly transgender people in my department, I would automatically be asked to represent a whole community that I did not know much about, other than my lived experience. I thought to myself: How does a transgender teacher from the Texas-Mexico border speak on gender and sexuality? What should I say? How should I approach Matt's piece? Needless to say, by the time I started reading, I was still new to learning queer theory. My background was in Mexican American Studies and mathematics education - two subjects that do not seemingly relate to queerness. However, that has been my life all along. I have lived and breathed binaries...but most of all, I have lived in the in-between, the gray areas, and the ambiguity that has been life.

Society is built to function in binaries. Everything around us, from clothes, religion, titles, the majority of restrooms, schools tell us that everyone is either a female or a male and nothing else. It is so deeply engrained in us that it is very hard to let go of. It is a concept that has been repeated for generations. Butler (2006) refers to this as a performance in her theory of performativity. I am not surprised when people 
misunderstand transgender and gender non-conforming issues, or fail to recognize their own dualistic views on the world, because there are few instances in school, if any, in which we are given the opportunities to deconstruct and reflect on our own biases. Where does my privilege come from? Do I, as a transgender man of color have privilege? If so, how does that affect others? How am I affected by others' privilege (such as Matt's)? I concluded that I can only speak from my experience, and how my personal experiences have affected the way I read Matt's viewpoint on his own White privilege. McIntosh (1990) wrote about her own deconstruction of her white privilege, and acknowledges such as an "invisible backpack of unearned assets," available to her as she sees fit (p.3). While privilege is largely racially and socioeconomically driven, there are those like myself, whose identities intersect (Crenshaw, 1989). That is, someone can belong to multiple marginalized groups according to race, gender, sexuality, and class simultaneously, among other groups.

Informed by Anzaldúa (1999) and Butler (2006), I understand living in a world in which metaphorical borders do not exist, that is, the world does not function in a binary, but has been socially constructed. We live in a world where borders distinguish us from "them", whoever the "other" might be (Tarman, 2017). As Anzaldúa wrote, "Los atravesados [sic] live here: the squint-eyed, the perverse, the queer, the troublesome, the mongrel, the mulato, the half-breed, the half dead; in short, those who cross over, pass over, or go through the confines of the "normal' (1999, p.25)". Who are the atravesados? They are those in between, those who do not fit society's standards of what a "normal" person should look and sound like. I am an atravesado.

When Etchells writes, "Now I embrace the other, I want to understand my privilege. The bifurcation that has been forced upon us -male/female, white/colored, tall/short, heterosexual/homosexual all fade away in the synthetical moment", he is like McIntosh (1990), trying to deconstruct his white privilege, in relationship to his gender and height privilege. However, I automatically saw the dualisms he had grown up learning in his language choice, excluding the "other", the atravesados, or those in between that have been marginalized by society. Our language choices affect us every day, sometimes subconsciously. There are people who are not female or male, in between white or colored (mixed race), not too short nor too tall, and not homosexual nor heterosexual, but bisexual, pansexual, demisexual, asexual, etc. The very notion of queer theory transcends categories (De Lauretis, 1991; Jagose, 1996), yet we still categorize ourselves. Anzaldúa (1999) writes, "There is something compelling about being both male and female, about having an entry into both worlds. Contrary to some psychiatric tenets, half and halfs are not suffering from a confusion of sexual identity, or seen from a confusion of gender. What we are suffering from is an absolute despot duality that human nature is limited and cannot evolve into something better. But I, like other queer people, am two in one body, both male and female. I am the embodiment of the hieros gamos [sic]: the coming together of opposite qualities within" (De Lauretis, 1991, p.41). History books have silenced many identities. Our dictionaries have failed us, as they have failed Matt, even as he is deconstructing his own privilege.

Is it possible to be able to learn about everything possible throughout one's schooling? I doubt it. Language evolves. Curriculum evolves. Identities evolve. We are now using terms in the queer community that no one could have imagined ten years ago. Being an ally to any community, especially one where we are not insiders, is an ongoing process, which does not end once you "discover" your own privilege. More than being understanding, it takes being a good listener and treating your fellow human being as you would like to be treated. Sometimes, it takes having to put yourself into uncomfortable positions where you are no longer in a state of privilege, which is understandably difficult to do. Looking at the world through a nonbinary lens takes a lot of work.

I am still un-learning my first 30+ years of "schooling" called life. We have to re-train ourselves into realizing whose perspective or place in history we silence by the very language we choose when talking to students, peers, family, friends, etc. Trouillot (1995), who writes about history, says "but the historicity of the human condition also requires that practices of power and domination be renewed. It is that renewal that should concern us most, even if in the name of our pasts. The so-called legacies of past horrors-slavery, colonialism, or the Holocaust - are possible only because of that renewal. And that renewal occurs only in the present. Thus, even in relation to The Past our authenticity resides in the struggles of our present. Only in that present can we be true or false to the past we choose to acknowledge (p.151)." What happens when a transgender person does not meet society's standards of what a male or female should look, act, and sound like? It is not necessary to personally know a lesbian, gay, bisexual, or transgender person to be able to empathize with the struggle that they have, especially those of color. We are not taught that transgender women of color are disproportionately victims of harassment and murdered at alarming rates.

McIntosh (1990) states, "In addition, since race and sex are not the only advantaging systems at work, we need similarly to examine the daily experience of having age advantage, or ethnic advantage, or 


\section{Chalklen}

physical ability, or advantage related to nationality, religion, or sexual orientation. Difficulties and dangers surrounding the task of finding parallels are many. Since racism, sexism, and heterosexism are not the same, the advantages associated with them should not be seen as the same (pp.15-16)." It is important to understand that someone's privilege means someone else's marginalization. Once we do this, we must then be open to discussing as a society if that is a world we want to exist in. I can by no means claim to be an expert at gender and sexuality. I am a work in progress.

\section{Warren L. Chalklen}

I enter this space triggered by Etchells thoughts. As I read and re-read the author's story, I am reminded of how the words of Hanish (1970) ring true, indeed, the personal is political. When I use the phrase "being triggered" I describe an internal process of frustration at the ways in which the author's learning often comes at the cost of others and how closely the author's story mimics my own. In an unforeseen way, I am forced to revisit my own story through the author's story. At the center of this juncture, between the author's reflection on his privilege and my own lived experience, I find myself puzzled by the task set before me. I am asking myself, "What is the value of reflecting on another white person's journey of enlightenment?"

Why was I asked to participate in this project? As I unpacked this question, I scrutinized why the author had selected me to co-author on this article. I sensed that my white maleness, South African of British descent and colleague status may have added to the comfort of what could be considered a vulnerable exercise. But, lingering in my analysis, I wondered whether the author believed I would respond to the reflections in a certain way because of our likeness across certain lines of intersectionality. Was the author looking for a sympathetic response to balance those of other authors?

With this backdrop, it is important for me to position myself in this piece. I am third generation, white South African male of British descent in my late-twenties and brother to a mixed-race sister who was born in 1994, the year apartheid ended. Growing up, race was always at the forefront of my existence. Being in public spaces with my sister, I often noticed how her experience differed from mine and later understood these differences to be attributed to her race. This understanding also spilled over in school when, being the first generation to attend integrated schooling; it was natural for those that look like me to thrive, and for those that did not look like me to be attributed as an example to their race when they were successful. Through making friends of color, I became more aware of the subtle ways our experiences differed, especially when colleagues more talented and able than me found themselves having to work harder to gain the same recognition I naturally got from white teachers.

But, recognizing racism did not make me exempt from participating in its system. As a white male, I was told, and everything around me confirmed, that what I worked for I would achieve. I grew up watching white actors in blackface and later listened to white radio hosts mocking black African accents. Never did any of this feel wrong. I saw myself as a good moral person who could not be racist because I had a sister of color. I rationalized her presence in my life abdicated me from being experienced as anything other than a champion of human dignity through diversity.

Now, as someone committed to destroying systems of oppression, I read the authors' reflection through an intersectional lens, hoping to problematize assumptions and explore overlap with my own experiences and perspectives. Collins (2000) summarizes by outlining four characteristics of intersectionality theory: 1) centering the lived experience, and specifically those of people of color and other marginalized groups; 2) complicating identity and examining both individual and group identities; 3) exploring identity salience as influenced by systems of power and privilege and unveiling power in interconnected structures of inequality; 4) advancing larger goal of promoting social justice and social change (Crenshaw, 1991, p.23). The following sections will explore these in more detail.

Centering the lived experience. Through the reflexive process, the author attempts to center their lived experience in order to demonstrate a process of privilege "awakening". In the second line the author states, "In this paper I deconstruct my privilege..." Through centering their lived experience and reflecting on their privilege, the author by extension privileges whiteness. Whiteness comprises many definitions including: identity development (Helms, 1993); privilege (McIntosh, 1989); sameness (Marshall, 2002); racial exclusion and control (Carter, 1997; Roediger, 1991; White, 1994); property (Harris, 1993; Kovel, 1984); and invisibility (Frankenberg, 1993). Jones (1977) synthesized racism literature and proposed three levels of racism: individual, where racism accounts for a person's belief system, including attitudes and behaviors designed to convince oneself of the superiority of whites and inferiority of black people and people of color; personally mediated, that is, prejudice or discrimination against black or people of color; and 
internalized, which encompasses accepted negative messages and stigmas by marginalized populations about their own group.

The author does not center whiteness only because he is a white male. The author's reflections center whiteness through omission of the ways in which the structures and systems of his world have produced the author's unearned positionality. It is not coincidental that the reflections focus on people and the context but does not dig into the physical world, which produces the real outcomes. Central to the notion of whiteness is the establishment of binaries. Binaries act to distribute, consolidate or enforce power. A subtext to the authors' reflection is learning about oneself through a binary relationship with the "other". Each stage of the author's life story is constructed through a dichotomous lens: growing up in England and noticing fellow class mates of color, living in the United Arab Emirates and interacting with local Emirati identified people and eventually studying in Texas and confronting the difference between himself and "them". In each context, the binary is set up as a tool to unearth the moments of learning. However, the dichotomy also serves as a mechanism of power centered on the author and away from "them".

Complicating and examining identify. The authors' reflections reveal that analyzing identity is not simple. Attempting to simplify the reflections to draw out themes of power and privilege deemphasized the nuances and complexities of human relationships. Specifically, how individual identity dynamically intersects with group identity and the structures of a society. Three central markers of identity permeated the author's reflections: race, gender and nationality. In each case these are complicated in an interlocking way. The author synthesizes this when he says, "I realized my male privilege in a feminism class. I realized my body privilege while doing performing arts. I realized my colonial privilege while teaching in the UAE."

While the author may have "realized" various forms of privilege at each stage, the nature of identity suggests that multiple forms of privilege and power operated simultaneously in each space even if the author was unaware. While he may have become intellectually aware of gender operating in the feminism class, he still brought power of the author's racial, socioeconomic status and nationality identity markers into that space. These identity markers may have acted to unfairly advantage him.

Regarding the operation of white privilege, McIntosh (1988) describes on her list of privileges that a white person, "I [A white person] can easily find academic courses and institutions, which give attention only to people of my race (p.2)". By not mentioning the racial make-up and history of the institution from within which the feminism class took place, the author may have omitted important markers of how the very institution, classroom and space that he occupied, supported his racialized privilege at the expense of others.

Scrutinizing gender, while the author becomes aware of his privilege, he seems unaware of how his privilege may have impacted the learning experiences of women in the class. Pittman (2010) interviewed seventeen faculty members about their experiences of teaching white male versus female students, she found that white male students 1) challenged their authority, 2) questioned their teaching competency, and 3) disrespected their scholarly expertise (p.187). Recognizing the impact of men on the learning experiences of women, Mary Daly, a tenured professor at Boston College refused to accept male students into her class contending that young men's presence in her feminist class would be distracting and disruptive to female students engaged in emotional and intellectual feminist debates (Ferdinand, p.1). There is a possibility that the process of the author reaching an "awareness" of his privilege may have come at the expense of the woman in the class and the instructor teaching the unit.

Exploring identity salience as influenced by systems of power and privilege. In this section I aim to explore the author's reflection of his time in the United Arab Emirates through the lens of systems of power and privilege. During this period of his life he worked in an "international" school as a teacher and as a teacher recruiter. Using the school as a focal point, I will analyze how the school, through its purpose and practices act to perpetuate the structures of inequality.

The site of the "international" school is a former British colony hiring British teachers demonstrates the insidious nature of colonization through education. Schools as institutions of social reproduction are fundamental to the project of perpetuating whiteness. The privately run school acts in a similar way to missionary schools during the colonial period. Luthuli (1981) describing the role of missionaries in South African colonization described how missionaries throughout the European occupation of South Africa became embedded in African society and used their allegiance with the Dutch and then the British Empire to disregard Indigenous education. The allegiance of the private school is not only to the continuation of western cultural values, but also to the accumulation of capital. For a private school, the children and parents of the United Arab Emirates are a market for profit seeking.

The school therefore is not a neutral space. It acts to institutionalize inequalities linked to capital within the United Arab Emirates society. In addition to exploiting the population to serve capital aims, the 


\section{Chalklen}

school also acts to perpetuate western ideals through curriculum. The author described the oppressive undertones of his own British education and how these played out in the recruitment of teachers but did not reflect on how these played out in the teaching of students. Regarding recruitment, the author describes, "We maintained our privileged status by perpetuating the assumption that white teachers are more educated than teachers from other countries." The subtext of the recruitment efforts of the teachers is to find teachers who embody the values of colonialism and by extension racial superiority. But the author does not fully reflect on the implications of making these same teachers responsible for the social, emotional and intellectual growth of diverse students.

Freire (1971) describes the banking approach to education as the ways in which students, as empty vessels, are filled by the teacher, and achieve education success through their reproduction of the teacher's knowledge, values and worldview (p.62). Freire's critique of the banking model of education reveals the danger inherent in the practice of hiring teachers specifically because they embody supremacist attitudes. According to Freire's (1971) model, the teachers' attitudes could become embedded in the students and ultimately lead to a situation where the student sees themselves through the eyes of the teacher. When the teacher views the student as inferior, the student may begin to see themselves as inferior as well. This situation negates the value of education. It constructs the presence of the school not as an emancipatory institution but a mechanism of control and reproduction of systems of control. Returning to the author's reflection, in pursuing a process of undermining the position of whiteness by reflecting only on privilege and not the implications of the structural tools of whiteness, such as colonial education, the author simultaneously reinforces the insidious nature of whiteness itself.

\section{Advancing the Larger Goal: Promoting Social Justice and Social Change}

The criteria of whether a text advances or undermines the larger goal of promoting social justice needs to be analyzed through praxis. On the one hand, it can be argued that the author is engaged in the practice of promoting social justice through his reflections, on the other, the author can be criticized for not including how his practice has shifted as a result of this reflection. By choosing not to explore the application of practice, it leaves the reader wondering what the larger goal of this overall exercise is.

Moreover, by explicitly foregrounding privilege in his analysis he backgrounds systemic power and its cost on others, especially those from marginalized groups. As he learns about himself, there is little acknowledgement of how his learning and life has intersected with others. Through this omission, the question of who and what this piece is ultimately for is raised.

\section{Conclusion}

Research of this deconstructive nature is critical to dismantling patriarchal hegemony. Each author offered a unique perspective based on lived experience and this led to nuanced responses and a deeper comprehension of privilege. Each researcher impacts and is impacted by the research and leaves with something different from the research process. All read the same text, but each researcher was drawn to different elements of the writing leading to five distinctive deconstructions. However, each deconstruction had an intersectionality with the others. Had more researchers deconstructed the initial text, those responses would have continued to deconstruct the text and this iterates an element of deconstruction in that it "has no fixed or expected endpoint or map, but rather a potentially infinite process (Holland, n.d.), therefore, there is the possibility to continue the deconstructive process by a third group of researchers deconstructing the deconstructions of the initial researchers. There is also the potential for the researchers to revisit this research at various points in their lived experience and deconstruct their current deconstruction. This process is only limited by the extent of continued interest by researchers and this is relative to the depth of the initial writing. If the initial deconstruction lacks authenticity, then all consecutive deconstructions will also be tainted by superficiality.

\section{Future Research}

Further research connote to the need to deconstruct privilege in a literary context and to develop autoethnography to fully delve into privilege beyond a superficial and neglectful narrative made during a snapshot in time. To procure deep analysis researchers interested in deconstructing their privilege are required to engage in perpetual reflection and acknowledge a sense of self-consciousness. 


\section{References}

Alanay, H., \& Aydin, H. (2016). Multicultural education: The challenges and attitudes of Undergraduate students in Turkey. Education and Science, 4l(184), 169-191.

Anzaldúa, G. (1999). Borderlands/La Frontera: The New Mestiza (2 eds.). San Francisco, CA: Aunt Lute Books.

Aydin, H., \& Koc-Damgaci, F. (2017). From Empire to Republic: Citizenship, Pluralism, and Diversity in Turkey. In James, A. Banks (Eds). Global Migration, Structural Inclusion, and Education across Nations [pp.351-377]. Washington, DC: American Educational Research Association (AERA) Press.

Bagguley, P., \& Hussain, Y. (2012). Riotous citizens: Ethnic conflict in multicultural Britain. Abingdon, Oxon: Ashgate Publishing, Ltd.

Behrens, J. (1997). Does the white racial identity attitude scale measure racial identity? Journal of Counselling Psychology, 44(1), 3-12. doi:10.1037/0022-0167.44.1.3

Bell, D. (1992). Faces at the bottom of the well: The permanence of racism. New York, NY: Basic Books.

Butler, J. (2006). Gender trouble: Feminism and the subversion of identity. New York, NY: Routledge.

Carr, A. (2015). The Inside Story of Starbucks' Race Together Campaign, No Foam. Fast Company. Retrieved from https://www.fastcompany.com/3046890/the-inside-story-of-starbuckss-racetogether-campaign-no-foam

Carter, R. T. (1997). Is white a race? Expressions of white racial identity. In M. Fine, W. L, C. Powell, \& M. Wong (Eds.), Off white: Readings on race, power and society. pp. 198-209. New York, NY: Routledge.

Case, K.A., Hensley, R., \& Anderson, A. (2014). Reflecting on heterosexual and male privilege: Interventions to raise awareness. Journal of Social Issues, 70(4), 722-740. doi:10.1111/josi.12088

Case, K.A., Iuzzini, J., \& Hopkins, M. (2012). Systems of privilege: Intersections, awareness, and applications. Journal of Social Issues, 68, 145-161. doi:10.1111/j.1540-4560.2011.01732.x

Citamak, Y. \& Yigit, H., I. (2012). From Student's Table to Teacher's Desk. International Journal of New Trends in Arts, Sports \& Science Education, 1(2), 1-7.

Collins, P. H. (2000). Gender, Black Feminism, and Black Political Economy. Annals of the American Academy of Political and Social Science, 568, 41-53. Retrieved from http://www.jstor.org/stable/1049471

Corona, R., Velazquez, E., Avila, M., McDonald, S.E., \& Neff, M. (2017). Ethnic labels, pride, and challenges: A qualitative study of Latinx youth living in a new Latinx destination community. Journal of Ethnic and Cultural Studies,4(1), 1. Retrieved from https://search.proquest.com/openview/adbe717364be1bd662bae6768d752b60/1?pqorigsite $=$ gscholar $\&$ cbl $=204598$

Coston, B., \& Kimmel, M. (2012). Seeing privilege where it isn't: Marginalized masculinities and the intersections of privilege. Journal of Social Issues, 68, 97-111. doi:10.1111/j.15404560.2011.01738.x

Crenshaw, K. (1989). Demarginalizing the intersection of race and sex: A Black feminist critique of antidiscrimination doctrine, feminist theory and antiracist politics. The University of Chicago Legal Forum, 139-167. Retrieved from https://philpapers.org/archive/CREDTI.pdf?ncid=txtlnkusaolp00000603

Damgaci, F. \& Aydin, H. (2013). Perceptions of higher education faculty members on multicultural education in Turkey. Dicle Üniversitesi Ziya Gökalp Eğitim Fakültesi Dergisi, 21(2), 314-331.

Damgaci-Koc, F. \& Aydin, H. (2014). An analysis of academicians' perceptions of multicultural education: A Turkish experience. The Anthropologist, 18(3), 817-833.

De Lauretis, T. (1991). Queer theory: Lesbian and gay sexualities (An introduction). Differences, 3(2), iiixviii.

Delgado, R. (1989). Storytelling for oppositionists and others: A plea for narrative. 87 MICH. L. REV. 2411-2415. Retrieved from http://heinonline.org/HOL/Page?handle=hein.journals/mlr87\&div=83\&g_sent=1\&casa_token=\&c ollection=journals

Dixon, L. (2007). The Nature of Black Presence in England before the Abolition of Slavery. Black Theology: An International Journal, 5(2), 171-183. doi:10.1558/blth2007v5i2.171 
Matthew J. Etchells ${ }^{1}$ Elizabeth Deuermeyer, Vanessa Liles, Samantha Meister, Mario Suarez, and Warren L. Chalklen

Dyson, M., Roediger, D., McIntosh, P., Meigs, A., \& Suarez, R. (2007). Membership has its privileges. In M. Dyson (Ed.), Debating race. New York, NY: Basic Civitas Book.

Feagin, J., Batur, P., \& Vera, H. (2001). White racism: The basics (2nd ed.). New York, NY: Routledge.

Ferdinand, P. (1999). Feminist teacher prefers all-woman class. Special to the Washington Post, Friday February 26, 1999. Retrieved from http://www.washingtonpost.com/wpsrv/national/daily/feb99/daly26.htm

Fine, M., Weis, L., Powell, C., \& Wong, M. (1997). Off white: Readings on race, power and society. New York, NY: Routledge.

Frankenberg, R. (1993). White women, race matters: The social construction of whiteness. Minneapolis, MN: University of Minnesota Press.

Freire, P. (1971). Pedagogy of the oppressed. London: England: Continuum.

Gifford, C., Halsall, J., \& Gill, S. S. (2012). The UK's Ad Hoc Multiculturalism and the Rise of Britishness. New York, NY: Routledge.

Giroux, H. A. (1997). White squall: Resistance and the pedagogy of whiteness. Cultural Studies, 11(3), 376389. doi:10.1080/095023897335664

Hanisch, C. (1969). The personal is political. Radical Feminism: A Documentary Reader, 113-16.

Harris, C. (1993). Whiteness as property. Harvard Law Review, 106(8). Retrieved from http://www.jstor.org/stable/1341787?seq=1\#page_scan_tab_contents

Helms, J. E. (1993). Racial identity and "racial" constructs. In E. J. Trickett, R. Watts, \& D. Birman (Eds.), Human Diversity. [pp. 285-311]. San Francisco, CA: Jossey-Bass.

Helms, J.E. (2017). The challenge of making Whiteness visible: Reactions to four Whiteness articles. The Counseling Psychologist, 45(5), 717-726. doi:10.1177/0011000017718943

Holland, N. J. (n.d). Deconstruction. Retrieved from http://www.iep.utm.edu/deconst/

Jagose, A. (1996). Queer theory: An introduction. New York, NY: NYU Press.

Johnson, L. (1999). My eyes have been opened. White teachers coming to racial consciousness. Paper presented at the American Education Research Association, Montreal, Canada.

Jones, C. P. (1977). Levels of racism: A theoretic framework and a gardener's tale. American Journal of Public Health, 90(8), 1212-1215. Retrieved from http://libezproxy.tamu.edu:2048/login?url=http://search.ebscohost.com/login.aspx?direct=true\&db=bth\&A $\mathrm{N}=3409838$ \&site $=$ eds-live

Joppke, C. (1999). Immigration and the nation-state: the United States, Germany, and Great Britain. Oxford, England: Clarendon Press.

Karataş, K., \& Oral, B. (2015). Teachers' perceptions on culturally responsiveness in education. Journal of Ethnic and Cultural Studies, 2(2), 47-57. Retrieved from https://search.proquest.com/openview/23752055e53d024288743d8342b721f0/1 ?pqorigsite $=$ gscholar $\& \mathrm{cbl}=2045987$

Keith, V. M,. \& Herring, C. (1991). Skin tone and stratification in the Black Community. American Journal of Sociology, 97, (3), 760-778. Retrieved from http://www.jstor.org/stable/2781783

Kopish, M. A. (2016). Preparing globally competent teacher candidates through cross-cultural experiential learning. Journal of Social Studies Education Research, 7(2), 75-108.

Kovel, J. (1984). White racism: A pshycohistory. New York, NY: Columbia University Press.

Lacan, J. (1960). The subversion of the subject and the dialectic of desire in the Freudian unconscious. In D. , K., Keenan (eds), Hegel and Contemporary Continental Philosophy, [pp.205-235]. New York, NY: State University of New York Press.

Ladson-Billings, G. \& Tate, W. F. (1995). Toward a critical race theory of education. Teachers College Record, 97, (1) 47-68. Retrieved from https://www.researchgate.net/profile/William_Tate/publication/279676094_Toward_a_Critical_Ra ce_Theory_of_Education/links/569803e908aea2d74375dba0.pdf

Lund, D.E. \& Carr, P.R. (Eds.). (2015). Revisiting the great white north? Refreaming whiteness, privilege and identity in education (2nd ed.). Rotterdam, Netherlands: Sense Publishers.

Luthuli, P. (1981). The philosophical foundations of black education in South Africa. Durban, South Africa: Butterworth.

Marshall, P. (2002). Cultural diversity in our schools. Belmont, CA: Wadsworth Group.

Martinez, E. (1993). Beyond Black/White: The racisms of our times. Social Justice, 20 (1/2), 22-34. Retrieved from http://www.jstor.org/stable/29766729 
McIntosh, P. (1988). White privilege and male privilege: A personal account of coming to see correspondences through Work in Women's Studies. Retrieved from http://libezproxy.tamu.edu:2048/login?url=http://search.ebscohost.com/login.aspx?direct=true\&db=eric\&A $\mathrm{N}=\mathrm{ED} 335262 \&$ site=eds-live

McIntosh, P. (1990). White privilege: Unpacking the invisible knapsack. Independent School, 49(2), 31-38.

McIntosh, P. (2012). Reflections and future directions of privilege studies. Journal of Social Issues, 68, 194206. doi:10.1111/j.1540-4560.2011.01744.x

Michou, A., Mouratidis, A., Ersoy, E., \& Uğur, H. (2016). Social achievement goals, needs satisfaction, and coping among adolescents. Personality and Individual Differences, 99, 260-265.

Memmi, A. (2013). The colonizer and the colonized. New York, NY: Routledge.

Collins, E. (2014, February) [Overview of Critical Race Theory, Video file]. Retrieved from https://www.youtube.com/watch?v=z-SffJkUt_U

Pinar, W. F. (2012). What is curriculum theory? (2nd ed.) New York, NY: Routledge.

Pinar, W. F., Reynolds, W., Slattery, P. \& Taubman, P. (1995). Understanding Curriculum. New York, NY: Peter Lang.

Pittman, C. T. (2010). Race and gender oppression in the classroom: The experiences of women faculty of color with White male students. Teaching Sociology, 38(3), 183-196. doi:10.1177/0092055x10370120

Rodney, W., Babu, A. M., \& Harding, V. (1981). How Europe underdeveloped Africa. Washington, D.C: Howard University Press.

Roediger, D. R. (1991). The wages of whiteness: Race and the making of the American working class. New York, NY: Verso.

Slattery, P. (2013). Curriculum development in the postmodern era: Teaching and Learning in an Age of accountability. (3rd Eds.). New York, NY: Routledge.

Slatton, B.C. (2014). Mythologizing black women: Unveiling white men's deep frame on race and gender. St. Paul, MN: Paradigm Publishing.

Smith, L., Kashubeck-West, S., Payton, G., \& Adams, E. (2017). White professors teaching about racism: Challenges and rewards. The Counseling Psychologist, 45(5), 651-668. doi: $10.1177 / 0011000017717705$

Solomos, J. (1989). The politics of immigration since 1945: Race and racism in Contemporary Britain. New York, NY: Springer.

Somiya, R. (2015). Starbucks Ends Tempestuous Initiative on Race. Retrieved from http://www.nytimes.com/2015/03/23/business/media/starbucks-ends-tempestuous-initiative-onrace.html?_r=0

Tarman, B. (2012). Prospective teachers' beliefs and perceptions about teaching as a profession, Educational Sciences: Theory \& Practice, 12(3), 1-24.

Tarman, B. (2017). Editorial: The future of social sciences. Research in Social Sciences and Technology, 2(2). Retrieved from http://ressat.org/index.php/ressat/article/view/329

Tatum, B. (1992). Talking about race, learning about racism: The application of racial identity development theory in the classroom. Harvard Educational Review, 62(1), 1-25. Retrieved from http://www.racialequitytools.org/resourcefiles/Talking\%20about\%20Racetatum.pdf

Trouillot, M. (1995). Silencing the past: Power and the production of history. Boston: Beacon Press.

UAE History. (n.d). Mohammed bin Rashid Intelligent Council. Retrieved from http://www.sheikhmohammed.com/vgn-exttemplating/v/index.jsp?vgnextoid=15e504ee11a11310VgnVCM1000004d64a8c0RCRD

White, T. W. (1994). The invention of the white race volume one: Racial oppression and control. New York: Verso.

Yurtseven, N., \& Altun, S. (2015). Intercultural sensitivity in today's global classes: Teacher candidates' perceptions. Journal of Ethnic and Cultural Studies, 2(1), 49-54.

Zulu. (1964). Outnumbered British soldiers do battle with Zulu warriors at Rorke's Drift. Retrieved from http://www.imdb.com/title/tt0058777/ April 28, 2015. 